\title{
Encoded visions of place at Dubai Creek
}

\author{
T. Kennedy \\ Department of Architecture, School of Architecture and Design, \\ American University of Sharjah, United Arab Emirates
}

\begin{abstract}
Dubai, one of the world's fastest growing cities, has created at breathtaking speed one of the world's largest waterfront developments. Much to the detriment of its ecology, multi-billion dollar projects, enormous human-made islands, are forming off its coast. The city's tourism trade is one of the largest sectors of its economy and has garnered international attention among travelers wishing to partake of luxurious Arabian ambience. At the heart of old Dubai are the districts that straddle the original creek; they harbor the original context of the city's ancient reputation as the most notorious port on the Arabian Sea. The contrast between the old and new Dubai is what attracts many of the tourists to its port center. Yet the new modernist narratives being set in place are at odds with the sustainability of the authentic experience that the Dubai Creek has to offer. An exploration of the place names around the creek points to a past intimacy between landscape and culture and tells a story that could inform how these tourist sites can retain their valuable resource of authenticity.
\end{abstract}

Keywords: sustainable tourism, sustainable urban form, cultural landscape, historic preservation, place theory, Arabian culture.

\section{Walking the ruined map of Dubai Creek}

"The past is not dead, it is not even past." - William Faulkner

The city of Dubai, caught in the grip of the current processes for Placemaking, has been rendered as mere spectacle, an ersatz destination manipulated by a tightly controlled set of computerized tableaux and identified by its global branding campaign. Yet there remain traces of the authentic city not yet flattened by the otherworldly images that falsely refer to a golden age of a long lost Orient. The creek itself and its adjacent districts are the source of the narrative told by its landscape and its inhabitants. But what of this storied place survives 
the modernist erasure by the hyper-reality engendered by the current urban makeover?

The Dubai Creek has continuously been an important harbor for ships sailing to various ports to the Arabian Gulf and countries of the Indian subcontinent and the east coast of Africa (see figure 1). Walking the map of streets and public alleyways of the old districts that straddle the Dubai Creek, one finds place names embedded like fossils in a map. Names derived from other unseen places that form an intertext, a locus of intersecting histories and place. In part because the people of the UAE are from a culture of the spoken word, the records and history books of the region lack definite historical names and dates. Place names are sometimes found in poetry and song without a geographical dictionary of reference. A case in point would be the myths that surround the origin of Dubai.

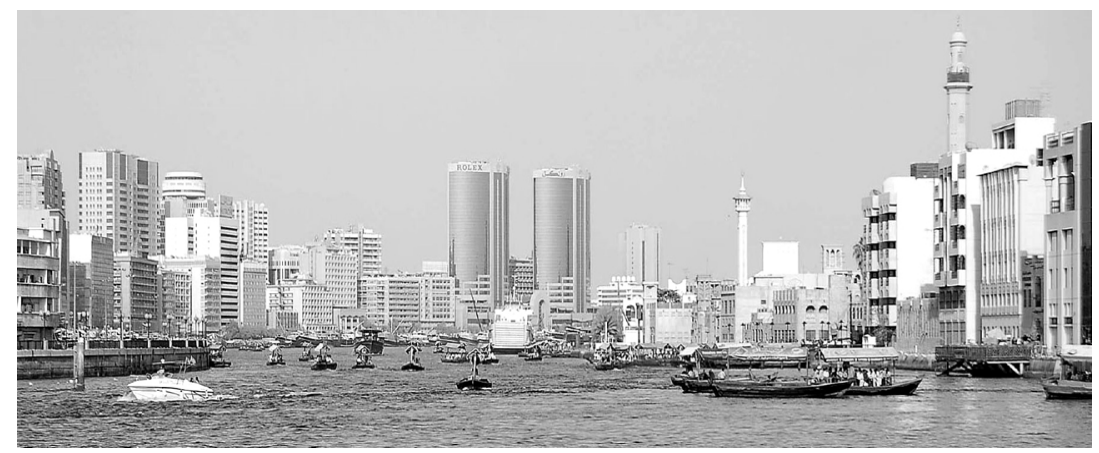

Figure 1: Abras ferrying passengers across Dubai Creek.

Some scholars maintain that the origin of the name Dubai has Arabic roots while others contend the name's origin is Persian. Many stories abound including one that says that the Arabic root word Daba is derived from the word $Y a d u b$, which means to creep. This word refers to the process by which the creek creeps from the sea into the dry land and is likened to the movement of a snake across the sand. Another story states that Dubai has a Persian etymology which translates the word's meaning as "having two sides". This story logistically refers to the settlement being defined by the two sides of the creek. Neither of the various origin stories can be verified through evidence but the city's moniker dates back to the $6^{\text {th }}$ century as a name of the location.

The Bastakiya district, which fronts the Creek with its multiple textile souks, is clearly a derivative of the province of Bastak on the southern shore of Iran and denotes the immigration and settlement of those Iranian merchants who travelled from across the gulf waters. Reading the rich palimpsest of the built environment bordering the creek involves unearthing the temporal depth of names as well as mapping their spatial narratives. The district on the north side of the creek is named Deira whose root meaning comes from the Arab word for circle and, as such, refers to the area as the home circle or home place. The Al Ras district in Deira means the head of land that defines the promontory that juts 
out into the creek. Following the line of the creek's edge from the head is Al Buteen, which akin to the belly (or its diminutive sense of tummy), is where water is collected and is situated in relation to the description of the profile of land as a body form. Naming the land according to human anatomy reflects an intimacy and assumed reverence for the localized ecology.

\subsection{Place names model local topos}

Naming is a fundamental strategy for making places. The named site becomes a storied place. Each name carries its own inception, the story of how it got its name. (Johnston 1) There are untold possibilities when landscape narratives are seen as entwined through lived experience. It's not so much that the places remind us of stories, but rather, they exist because of the stories associated with them (Johnston 2). The stories encoded in the collage of place names require an act of recovery to make them intelligible to the tourist. Incorporating place narratives into the built fabric of the historic districts along the Dubai Creek could be designed as a pattern of way-finding for tourists seeking to penetrate the exuberant diversity of its streets and alleyways (see figure 2). Little known, the labyrinthine network of pedestrian alleyways set off of the vehicular streets offers the peripatetic traveller a view of daily life hidden from the thoroughfare. The courtyards that exist where the alleys converge are the sites of a condition of the public domain that doesn't know its name. Atmospheric of a past time, the public alleys create a system of open space that inhabits and connects a pedestrian web of commercial and social interactions (see figure 3).

Contrary to wilderness places, such as the Empty Quarter that are unknown as places, the sites of old Dubai are saturated with meaning. They resist being turned into the typical tabla rasa of the modernized site cleaned of all local associations. A multitude of stories compete for attention and do so with conflicting interpretations and story lines. A palimpsest in ancient times denoted writing material (as a parchment or tablet) used one or more times after earlier writing has been erased. It can also be used as a metaphor of the traces of diverse layers apparent beneath the surface of the built environment. The districts that straddle the Dubai Creek reveal through their place names a palimpsest linked to the narrative between Landscape and Culture. With assistance by Dr. Amer Moustafa with the translation from Arabic to English, the following list of place names of the districts on both sides of the creek evidence this connection:

1. Al Rigga district - refers to a landscape pattern where a shallow water table precipitates the ease of digging water well.

2. Al Ghubaibah district - named for the small scale vernal pools that form in the area situated close to the mouth of the creek.

3. Muraqqabat district - named because of the design of its water wells. Muraqqabat means "those of the long neck" and describes the tall stone collars that ringed the wells' openings.

4. Nakheel district: Nakheel is the plural (like fish) meaning a group of Palm trees and described the vegetative pattern of the area.

5. Dhaghaya district: named for its close proximity to the sea and its inhabitants of fisherman. 
6. Al Wuhelda district: named for a single landmark Palm tree that distinguished this place.

7. Al Barsha district: named after the planting of trees in groups, which looked like a decorated landscape.

8. Al Muteena district: named as the land of mud

9. Umm Rumool district: named after sand dunes consisting of soft sand, which has certain characteristics.

10. Abu Hail district - named after the well of potable water that marked this place.

11. Al Qusais district - one legend has this historic area named after the rag roog plant in the Al Uthnien family group of trees.

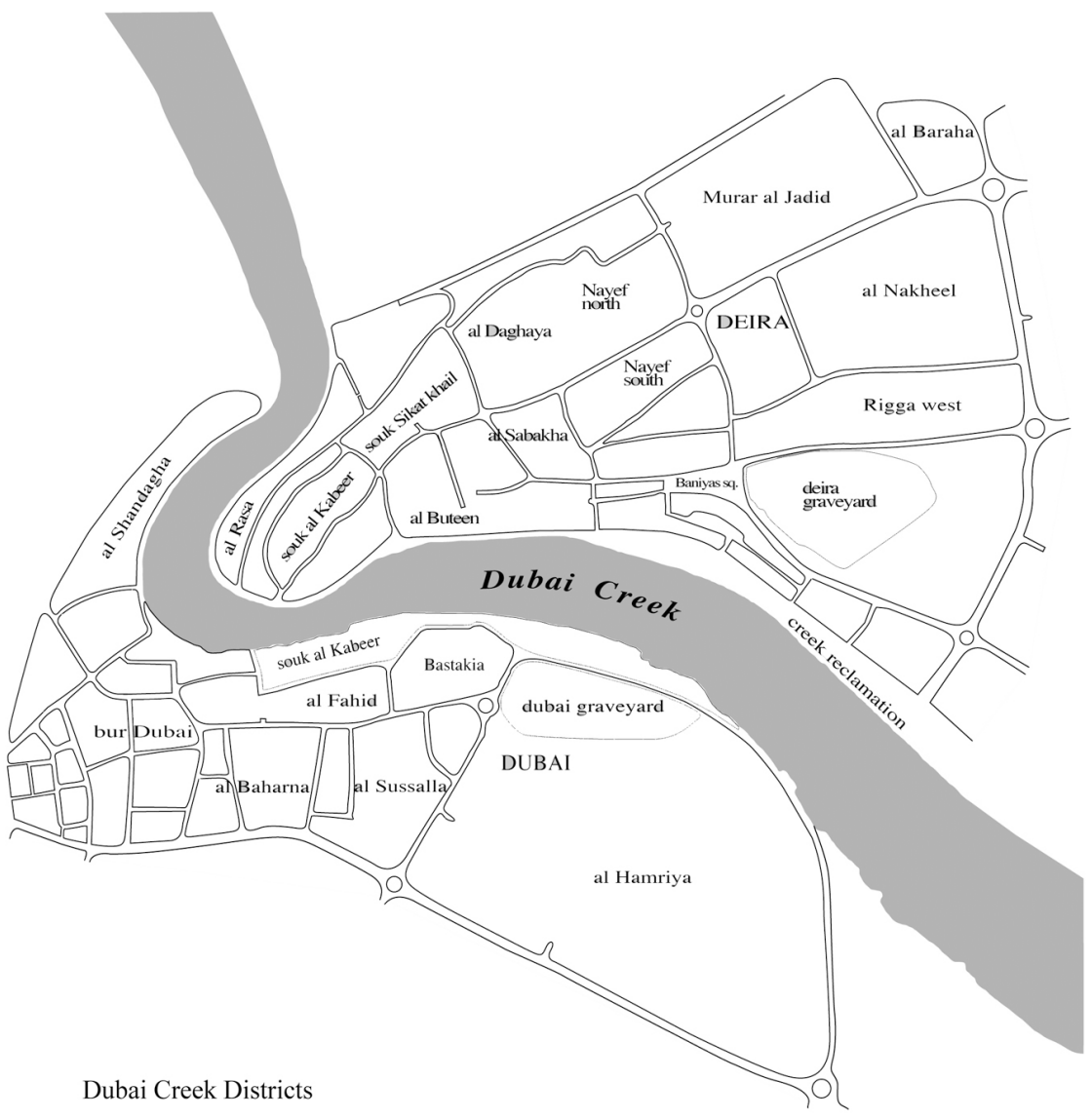

Figure 2: $\quad$ Map of Dubai Districts circa 1965. 


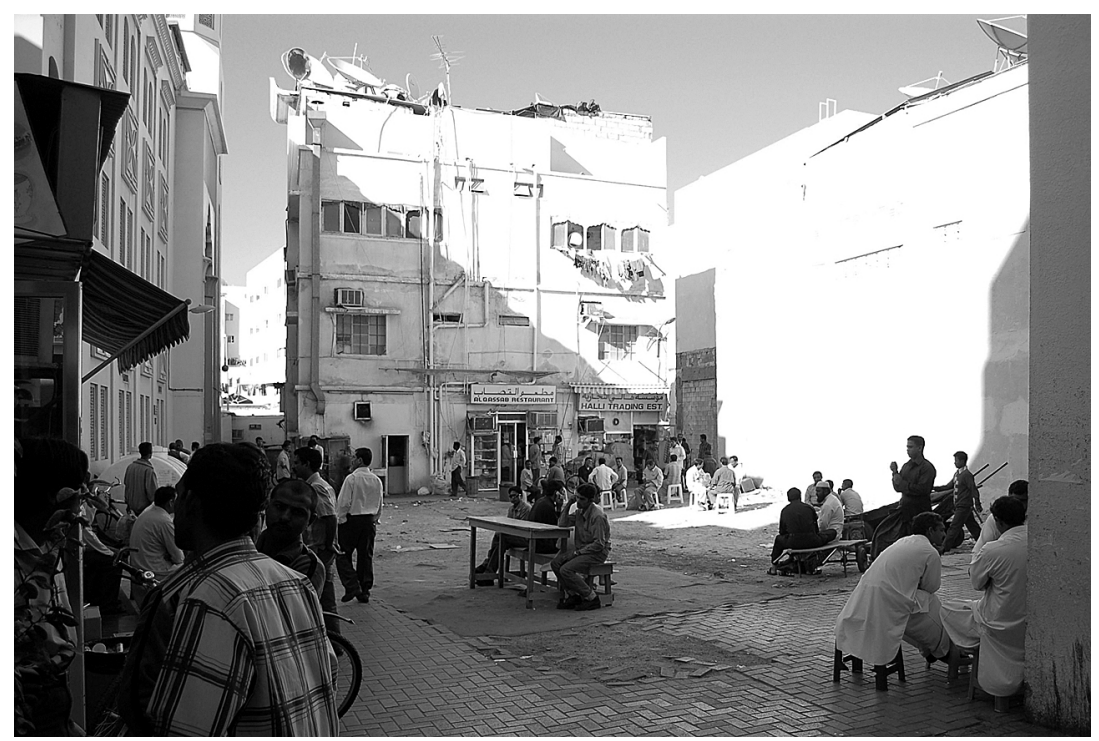

Figure 3: Where alleyways lead to Dubai's little known public space.

Opposing this congruency between 'genus loci' and place name are many of the modern tourist sites in Dubai: Dubailand, Internet City, Media City, International City, The Greens, and The Meadows often evoke their own versions of narrative topos but with reference to other mythologies and imaginative literature outside the historic context of the UAE. The place names along the Dubai Creek provide a framework map as palimpsest, a temporal collage marking various episodes of origin, settlement and change. The persistence and accumulation of names create important juxtapositions of different times and their stories.

\section{Archetypal identity of place}

The differentiations of the modern world have the same structure as the tourist attractions: elements dislodged from the original natural, historical and cultured context, fit together with other such displaced and modernist things and people. The differentiations are the attractions where an ancient weathered dhow is berthed next to a modern yacht; an old world souk is housed across the street from a multi-storied commercial mall. This juxtaposition simultaneously separates these things from those originally figured cultural elements and brings the people liberated from traditional attachments into the modern world where as tourists they may attempt to discover or reconstruct a cultural history or identity (MacCannell, 1999). Dubai famously offers a wide spectrum of tourist scenarios that range from expansive white sand beaches, elaborately franchised desert oases to man-made snow-covered ski slopes. 
Honorific names were not foreign to the native emirati. The Umm Hurair district next to the Bastakiya district was so named for a legendary lady who had many, many cats. On the Deira side of the creek the Naif district was named by a legendary poet after "the Tall One"; Naif being a proper noun. This tall archetypal figure was the guardian of the district. The Hor Al Anz district was named after a legendary racehorse whose owner having retired his favored steed, allowed her to roam this area of Deira. She was later buried in this lowland (Hoor) district. Baniyas Square in the Al Buteen district of Deira was named for the members of the Baniyas tribe who would gather in the square's open space to begin their return caravan back to Abu Dhabi. The same square was supposed to be named as a memorial for the Egyptian president Gamal Abdel Nasser but the absence of signage in the square indicates political erasure. This square and several other sites in the area will soon be affected by the proposed Dubai Metro system scheduled to run underground through the district. While this new system is expected to relieve ground traffic, it will also create a new means of conveyance for tourists to the area.

Names figure in the narrative plots surrounding questions of identity; giving presence to unknown, taking possession of space, interpreting and remembering the past, and reclaiming connections to place, history and nature. (Potteiger, 2000) Currently under construction in close proximity to the Burj Dubai, whose final height will give it the distinction of the world's tallest building, the developers Emaar UAE are advertising properties for "The Old Town". As Emaar's website states: "The development ranges from low-rise three storey apartment buildings to a number of exclusive mid-rise buildings with Penthouses. Architectural cues are taken from traditional buildings, including the Al-Bastakia neighbourhood of Bur Dubai and the residences of Sheikh Saeed AlMaktoum and Mohammed Shareef Boukash - with textures that reflect the gypsum, clay or sarjool plastering used in the early twentieth century." ("Old Town", 2007) With its unrelenting economic growth, Deira's future development could well follow a narrative that includes the abandonment of the city's historic port for the world of high finance. The area could devolve into a state of no identity except a "poly-identity" suitable for whatever is projected into it... a faceless place blurred into one (Beauregard [5]). At the end of the central axis of the nearly completed man-made island "Palm Jumeirah" the 2,000 room Atlantis Hotel is scheduled for completion in 2008. Based on the mythical lost continent of Atlantis, the hotel will be similar to its twin Atlantis Hotel in the Bahamas. Adjacent to the hotel is a proposed archeological attraction entitled "The Dig" where tourists can search among faux ruins and extract imbedded "specimens" as keepsakes. The tourist ensconced in his destination resort is sold a fabricated replica of the past (presumably manufactured in a distant Third World country) as a substitute for the authentic encounter with the place-telling of Dubai. Adjacent to the existing waterfront, the proposed "Palm Deira" will be twice the size of the "Palm Jumeriah" drastically changing the character of Deira's "Old Town".

Place is directly aligned with memory and how individuals remember a space. Mark Turner, in his book Literary Mind, wrote, "Narrative imagining - story - is 
the fundamental instrument of thought. It is our chief means of looking into the future, of predicting, of planning, of explaining. Most of our experience, our knowledge, and our thinking are organized as stories." (Turner [6]) Erasure of the collective memory and place identity can be appraised by a sustainable approach to the local identity of the creek. Foregrounding the cultural narratives would inform those tourists desirous of experiencing what makes Dubai different from the other destination resorts they would have the opportunity to visit. Sustaining this cultural resource would also tell the tale of lived experience to a current population and provide them with an immediate connection between their environment and their self-interest. One of the basic strategies of any sustainable approach must be to avoid the risk of irreversible losses of our sustainable resources. Learning to read the complex spatial narrative of a map goes beyond the curious names. While physical forms of early settlement may have vanished, the names that persist still speak of the symbolic life of generational community.

\section{Conclusion}

The place names, coding place-telling into stories, are evidence of the past inhabitants, sustainable integration with the surrounding environs. As Kristina Hill writes, "they support, a vision of sustainability with messages suggesting: 1) cultivation of insight into the sustainable challenges that we face; 2) avoid the human tendency towards ideological and technological hubris; and 3) perceive the patterns in our landscapes that have implications for ecological processes and human health." (Hill [7]). The districts that border both sides of the Dubai Creek are framed by re-presentations of the past functions of public and private life. The old creek makes visible for the ephemeral tourist a tangible view of its society and its works. This framed habitat is in stark contrast to the destination resorts and franchised bubbles that house the flux of tourists.

The past nature of the creek is made part of the present, not in the form of some reflected spirit of the place, but as revealed in the objects on view as tourist attractions. The work activities that continue the commercial operations along the creek are front-staged as a work-display tableau for the tourist's leisurely perusal (see figure 4). Authenticity of experience is the tourist's remains the coin of the realm and is measured against the familiar franchise conglomerate fantasies manufactured for their consumption. The ongoing activity of dhows docking from the sub-continent to unload their cargo destined for the nearby souks is not a costumed drama staged for visitors benefit but a timeless activity that continues to serve the creek-side settlement. The ongoing narrative along the creek reaches back to ancient times and the accumulation of its stories staggers the imagination to understand the depth of its history. One constant that keeps the past from overwhelming the present is the constant flow of water that washes away the past and keeps both its shores in an eternal present. 


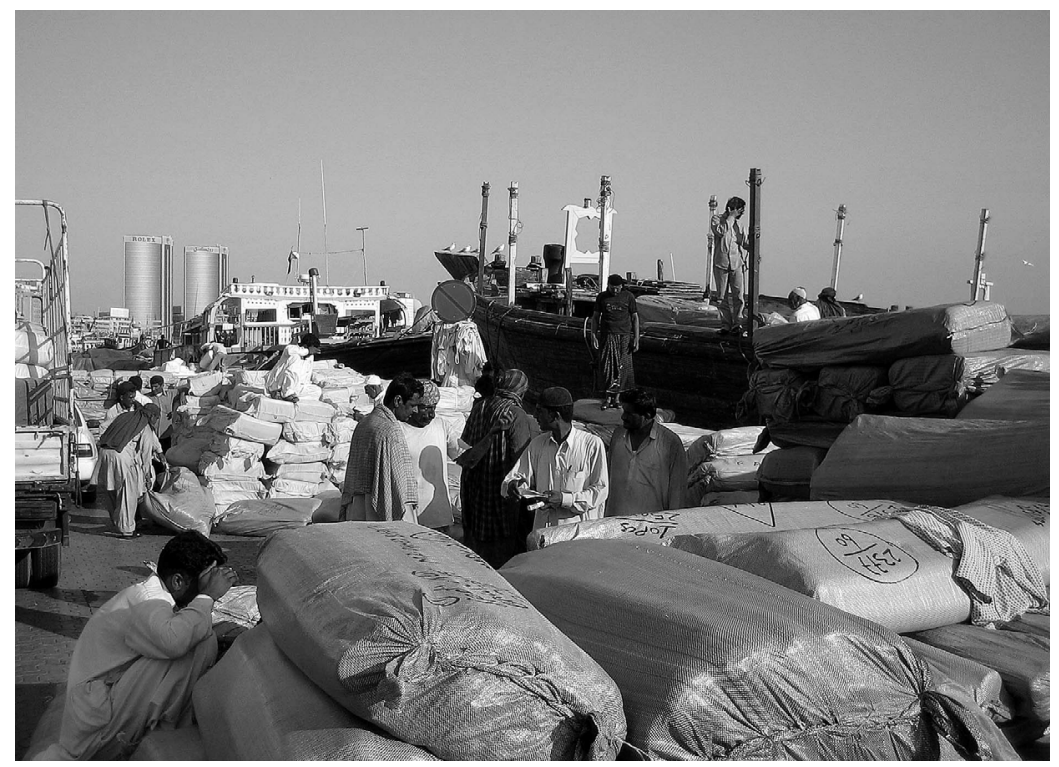

Figure 4: Dhow workers along the tourists' path at the creek.

\section{References}

[1] Johnston, Barbara. Stories, Community, and Place: Narratives from Middle America, Bloomington: Indiana Press, p. 120, 1990.

[2] MacCannell, Dean. The Tourist: A New Theory of the Leisure Class, Berkeley: University of California Press, pps. 13-14, 1976.

[3] Potteiger, Matthew. Landscape Narratives: Design Practices for Telling Stories, New York: John Wiley \& Sons, pg. 15, 1998.

[4] Emaar UAE Developments. (n.d.). Retrieved from http://www.emaar.com/Developments/Downtown/oldtown/Index.asp, March 20, 2007.

[5] Beauregard, Robert A. From Place to Site: Negotiating Narrative Complexity. In Burns, Carol and Kahn, Andrea (Eds.), Site Matters, London: Routledge, pps.39-58, 2005.

[6] Turner, Mark. The Literary Mind: The Origins of Thought and Language, Cambridge, MA: Oxford University Press, pps. 4-5, 1998

[7] Hill, Kristina. In Benson, J. and Roe, M. (Eds.), Landscape and Sustainability, London: Spon Press, pps 296-297, 2000. 